\title{
Extracellular expression and characterization of an $\alpha$-glucosidase from Oryza sativa and its transglycosylation for synthesis of 2-O- $\alpha$-D-glucopyranosyl-L-ascorbic acid
}

\author{
Xuelian $\mathrm{Qi}^{1}$, Junlan Shao ${ }^{1}$, Yinchu Cheng ${ }^{1}$, Xiaoying $\mathrm{He}^{1}$, Yan $\mathrm{Li}^{1}$, Honghua Jia ${ }^{1}$, and \\ Ming Yan $^{1}$ \\ ${ }^{1}$ Nanjing Tech University
}

May 14, 2021

\begin{abstract}
Abstract: 2-O- $\alpha$-D-Glucopyranosyl-L-ascorbic acid (AA-2G) is an important industrial derivative of L-ascorbic acid (AA), which has the distinct advantages of non-reducibility, antioxidation, and reproducible decomposition into L-ascorbic acid and glucose. Enzymatic synthesis is a preferred method for AA-2G production over alternative chemical synthesis owing to the regioselective glycosylation reaction. $\alpha$-Glucosidase, an enzyme classed into O- glycoside hydrolases, may be used in glycosylation reactions to synthesize AA-2G. Here, one $\alpha$-glucosidase from Oryza sativa (rAGL) was recombinantly produced in Pichia pastoris GS115 and used for biosynthesis of AA-2G with few intermediates and byproducts. The extracellular rAGL reached $9.11 \mathrm{U} / \mathrm{mL}$ after fed-batch cultivation for $102 \mathrm{~h}$ in a 5 -L fermenter. The specific activity of purified rAGL is $49.83 \mathrm{U} / \mathrm{mg}$ at $37^{\circ} \mathrm{C}$ and $\mathrm{pH} 4.0$. The optimal temperature of rAGL was $65{ }^{\circ} \mathrm{C}$, and it was stable below $55^{\circ} \mathrm{C}$. rAGL was active over the range of pH 3.0-7.0, with the maximal activity at $\mathrm{pH} 4.0$. Under the condition of $37^{\circ} \mathrm{C}, \mathrm{pH} 4.0$, equimolar maltose and AA·Na, 8.7 $\pm 0.4 \mathrm{~g} / \mathrm{L}$ of AA-2G was synthesized by rAGL. These studies lay the basis for the industrial application of recombinant $\alpha$-glucosidase. Keywords: $\alpha$-Glucosidase; Oryza sativa; 2-O- $\alpha$-D-glucopyranosyl-L-ascorbic acid; Transglycosylation; Pichia pastoris
\end{abstract}

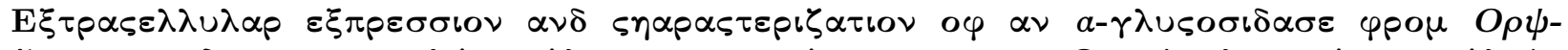

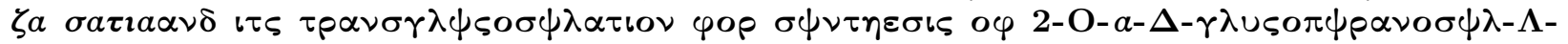

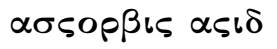

Xuelian Qi, Junlan Shao, Yinchu Cheng, Xiaoying He, Yan Li*, Honghua Jia*, Ming Yan

College of Biotechnology and Pharmaceutical Engineering, Nanjing Tech University, Nanjing 211816, China

* Corresponding author. Tel.: +86-25-58139368; Fax: +86-25-58139368

liyan@njtech.edu.cn (Y.Li); hhjia@njtech.edu.cn (H. Jia)

\section{Abstract:}

2-O- $\alpha$-D-Glucopyranosyl-L-ascorbic acid (AA-2G) is an important industrial derivative of L-ascorbic acid (AA), which has the distinct advantages of non-reducibility, antioxidation, and reproducible decomposition into L-ascorbic acid and glucose. Enzymatic synthesis is a preferred method for AA-2G production over alternative chemical synthesis owing to the regioselective glycosylation reaction. $a$-Glucosidase, an enzyme classed into $O$ - glycoside hydrolases, may be used in glycosylation reactions to synthesize AA-2G. Here, one $\alpha$-glucosidase from Oryza sativa (rAGL) was recombinantly produced in Pichia pastoris GS115 and used for biosynthesis of AA-2G with few intermediates and byproducts. The extracellular rAGL reached $9.11 \mathrm{U} / \mathrm{mL}$ after fed-batch cultivation for $102 \mathrm{~h}$ in a 5 -L fermenter. The specific activity of purified rAGL is $49.83 \mathrm{U} / \mathrm{mg}$ at $37{ }^{\circ} \mathrm{C}$ and $\mathrm{pH} 4.0$. The optimal temperature of rAGL was $65{ }^{\circ} \mathrm{C}$, and it was stable below $55{ }^{\circ} \mathrm{C}$. rAGL was 
active over the range of $\mathrm{pH} 3.0-7.0$, with the maximal activity at $\mathrm{pH} 4.0$. Under the condition of $37^{\circ} \mathrm{C}, \mathrm{pH}$ 4.0, equimolar maltose and AA·Na, $8.7 \pm 0.4 \mathrm{~g} / \mathrm{L}$ of AA- $2 \mathrm{G}$ was synthesized by rAGL. These studies lay the basis for the industrial application of recombinant $a$-glucosidase.

Keywords: $a$-Glucosidase; Oryza sativa ; 2-O- $a$-D-glucopyranosyl-L-ascorbic acid; Transglycosylation;

Pichia pastoris

\section{Introduction}

L-Ascorbic acid (L-AA) is a water-soluble vitamin, commonly known as vitamin C (VC), which participates in various physiological activities and plays an important role in maintaining and promoting human health $^{[1-3]}$. VC is an essential nutrient that cannot be synthesized by the human body, and must be obtained from foods and supplements ${ }^{[4-5]}$. However, the extreme instability in aqueous solutions, especially under specific oxidation conditions, directly reduces its biological activity, resulting in its applications being greatly restricted ${ }^{[6-9]}$. In order to maintain the same biological activity and improve its stability, various VC derivatives including ascorbyl phosphate, ascorbyl sulfate ${ }^{[10-11]}$, ascorbyl palmitate ${ }^{[12-13]}$ and ascorbyl glucoside $^{[14-15]}$ have been chemically or biologically synthesized, among which $2-\mathrm{O}-\alpha-\mathrm{D}$-glucopyranosyl-Lascorbic acid (AA-2G) is extremely stable and nonreducible, which has attracted considerable attention with its wide range of applications in cosmetics, food, and medicine ${ }^{[16-17]}$.

Enzymatic synthesis is a preferred method for AA-2G production over alternative chemical synthesis owing to the regioselective glucosylation reaction ${ }^{[16]}$. Up to now, AA-2G has mainly been synthesized by transglucosylation of L-AA catalyzed by several enzymes, including $\alpha$-glucosidase ${ }^{[18-19]}$, cyclodextrin glycosyltransferase (CGTase) ${ }^{[20-21]}$, amylase ${ }^{[22]}$, sucrose phosphorylase ${ }^{[23-24]}$, and $\alpha$-isomaltosylglucosaccharide synthase ${ }^{[25]}$. Among them, the synthesis of AA-2G by $\alpha$-glucosidase from higher eukaryote such as rice seed and mammals has the advantages of less intermediates and by-products ${ }^{[18,26,27]}$. However, due to the low efficiency and limited source of glycoside hydrolases, there are only a few related reports in recent years $[16,28]$.

$a$-Glucosidase (AGL; EC 3.2.1.20), mainly classified into the glycoside hydrolase families GH13 and GH31, represents a group of exoglycosidases widely distributed in microorganisms, plants, and animals, which can react with the $a$-glucosidic bond at the nonreducing terminal of substrates and release $a$-glucose ${ }^{[29]}$. Under high substrate concentration, GH31 AGL can also catalyze transglucosylation to synthesize oligosaccharides or other $\alpha$-glucosylated compounds ${ }^{[29-30]}$. The glycosylated hydroxyl group of the receptor of $\alpha$-glucosidase transglycosylation activity is independent on its hydrolysis specificity, and the substrate specificity of GH 31 AGL hydrolysis activity varies with enzyme source ${ }^{[31]}$. It is possible to synthesize AA-2G by glycoside hydrolases belonging to family GH31, because these are retaining enzymes with the catalytic mechanism allowing them to act as transferases. The pattern of transglycosylation products of glycoside hydrolase mainly depends on the structure of the enzyme, especially its catalytic center ${ }^{[32-34]}$.

Pichia pastoris is the excellent expression host with well-established genetic tools and cultivation strategies for scale-up producing heterologous proteins, particularly industrial enzymes and biopharmaceuticals [35]. Several AGL fromAspergillus species ${ }^{[28,36,37]}$ and Apis cerana indica ${ }^{[38]}$ have been successfully expressed in P. pastoris . The inducible alcohol oxidase I promoter $\left(\mathrm{P}_{\mathrm{AOX} 1}\right)$ and the constitutive glyceraldehyde3-phosphate dehydrogenase promoter $\left(\mathrm{P}_{\mathrm{GAP}}\right)$ are commonly used in genetic engineering of P. pastoris . Unlike $\mathrm{P}_{\mathrm{AOX} 1}, \mathrm{P}_{\mathrm{GAP}}$ simplifies the cultivation by avoiding the use of toxic methanol as a carbon source and inducer ${ }^{[39]}$. In the present study, the AGL gene fromOryza sativa was codon-optimized and synthesized for extracellular production of the rAGL in $P$. pastoris under the regulation of $\mathrm{P}_{\mathrm{GAP}}$. The rAGL was characterized, and its potential for AA2G production via transglycosylation of L-AA was investigated.

\section{Experimental Section}

\subsection{Strains, media, and chemicals}

Escherichia coli DH5 $\alpha$ (TransGen Biotech, Beijing, China) and P. pastoris GS115 (Invitrogen, Carlsbad, 
USA) were used as the host strains for DNA cloning and protein expression, respectively. The plasmid pPIC9K (Invitrogen, Carlsbad, USA) was selected as a backbone vector to generate the recombinant expression vectors for $P$. pastoris.

E. coli $\mathrm{DH} 5 \alpha$ was grown at $37^{\circ} \mathrm{C}$ in Luria-Bertani (LB) medium $(50 \mathrm{mg} / \mathrm{mL}$ Kanamycin supplemented when necessary). Yeast strains were cultivated in the yeast extract peptone dextrose (YPD) medium, buffered minimal glycerol (BMGY) medium, or minimal dextrose (MD) medium following the pPIC9K manual. YPD medium containing different concentrations of G418 sulfate (geneticin, Yuanye Bio-Technology, Shanghai, China), which is applied to select geneticin resistant strains.

FastPure Plasmid Mini Kit and Taq DNA polymerase were obtained from Vazyme (Nanjing, China). The restriction enzymes were purchased from New England Biolabs (Beverly, USA). The nucleotide sequences used in this study were synthesized by Genscript (Nanjing, China). D-Glucose assay kit based on the combined action of glucose oxidase (GOD) and peroxidase (POD), was obtained from Yuanye Bio-Technology Co., Ltd (Shanghai, China). AA-2G was purchased from Tokyo Chemical Industry Co. Ltd. (Japan).

\subsection{Plasmid construction and transformation}

According to the $P$. pastoris GS115 chromosome, the sequence of $\mathrm{P}_{\mathrm{GAP}}$ (Supplementary Data 1) was synthesized and cloned between $S a c$ I and Bam HI restriction sites of pPIC9K, generating the plasmid pGAP9K with $\mathrm{P}_{\mathrm{GAP}}$. The AGL (UniProtKB accession no. Q653V7) encoding sequence from the Oryza sativa subsp. japonica (Rice) was synthesized with optimized codons for heterologous expression in P. pastoris (Supplementary Data 1), and inserted into the Eco RI site of pGAP9K with a 6-histidine tag at the $N$-terminus to replace the original signal peptide of AGL (1 - 33 amino acid residues), thus obtaining the plasmid pPIC9K-AGL. (Fig. 1).

\section{Figure 1}

Plasmid transformations were performed according to a condensed electroporation protocol previously described $^{[40]}$. The plasmid pGAP9K-AGL was linearized withPsh AI and introduced into P. pastoris GS115 by electroporation to facilitate integration into the host genome. Multi-copy inserts of the transformants were selected by MD plates and the grown clones were transferred to YPD plates containing different concentrations of geneticin $(0.5 \mathrm{mg} / \mathrm{mL}, 1 \mathrm{mg} / \mathrm{mL}, 2 \mathrm{mg} / \mathrm{mL}, 3 \mathrm{mg} / \mathrm{mL} \text {, and } 4 \mathrm{mg} / \mathrm{mL})^{[41]}$. The geneticin-resistant clones were confirmed by Polymerase Chain Reaction (PCR) amplification with pairs of primers listed in Supplementary Table 1, and the PCR-positive clones were selected for the consequent expression tests. As a negative control, transformation was also performed using only the Psh AI linearized pGAP9K vector.

\subsection{Expression of AGL in P. pastoris}

Well-grown colonies were incubated in $5 \mathrm{~mL}$ of YPD medium $(10 \mathrm{~g} / \mathrm{L}$ yeast extract, $20 \mathrm{~g} / \mathrm{L}$ peptone, and $20 \mathrm{~g} / \mathrm{L}$ glucose) and grew overnight at $30^{\circ} \mathrm{C}$ and $200 \mathrm{rpm}$. Then, $0.5 \mathrm{~mL}$ of the culture was inoculated into $50 \mathrm{ml}$ of BMGY medium ( $2 \%$ glycerol, $1 \%$ yeast extract, $2 \%$ peptone, $1.34 \%$ yeast nitrogen base w/o amino acids, $4 \times 10^{-5} \%$ biotin and $100 \mathrm{mM}$ sodium phosphate buffer, $\mathrm{pH} 6.0$ ) in a 250-mL flask and incubated at $30^{\circ} \mathrm{C}$ and $200 \mathrm{rpm}$. When the culture turbidity $\left(\mathrm{OD}_{600}\right)$ reached approximately $18-20$, it was centrifuged $(2000 \times \mathrm{g})$ for $10 \mathrm{~min}$ at $4{ }^{\circ} \mathrm{C}$ and the cell pellet was resuspended in $200 \mathrm{~mL}$ of BMGY ${ }^{[42]}$. The cells were cultured at $30{ }^{\circ} \mathrm{C}$ and $200 \mathrm{rpm}$ for another $72 \mathrm{~h}$. Glucose was added every $12 \mathrm{~h}$ to a final concentration of $1 \%$. The cell culture $(1 \mathrm{~mL})$ was separated by centrifugation at $6,000 \times g$ for $10 \mathrm{~min}$ and the supernatant was kept at $4{ }^{\circ} \mathrm{C}$ for AGL activity assay.

The recombinant $P$. pastoris with the highest yield of AGL was used for scale-up fermentation in a 5-L fermenter. The fermentation began in $2 \mathrm{~L}$ Basal Salt Medium ( $4 \%$ glycerol, $26.7 \mathrm{~mL} 85 \% \mathrm{H}_{3} \mathrm{PO}_{4}, 0.93 \mathrm{~g}$ $\mathrm{CaSO}_{4}, 18.2 \mathrm{~g} \mathrm{~K}_{2} \mathrm{SO}_{4}, 14.9 \mathrm{~g} \mathrm{MgSO}_{4} \cdot 7 \mathrm{H}_{2} \mathrm{O}, 4.13 \mathrm{~g} \mathrm{KOH}$ and $2 \mathrm{~mL} 5 \%$ antifoam) containing $4.35 \mathrm{~mL} / \mathrm{L}$ PTM1 salt solution $\left(2 \mathrm{~g} / \mathrm{L} \mathrm{CuSO}_{4} \cdot 5 \mathrm{H}_{2} \mathrm{O}, 7 \mathrm{~g} / \mathrm{L} \mathrm{ZnCl} 2,0.08 \mathrm{~g} / \mathrm{L} \mathrm{NaI}, 22.0 \mathrm{~g} / \mathrm{L} \mathrm{FeSO}_{4} \cdot 7 \mathrm{H}_{2} \mathrm{O}, 3.0 \mathrm{~g} / \mathrm{L} \mathrm{MnSO}_{4} \cdot 7 \mathrm{H}_{2} \mathrm{O}\right.$, $0.2 \mathrm{~g} / \mathrm{L}$ biotin, $0.2 \mathrm{~g} / \mathrm{L} \mathrm{Na}_{2} \mathrm{MoO}_{4} \cdot 2 \mathrm{H}_{2} \mathrm{O}, 0.02 \mathrm{~g} / \mathrm{L}$ boric acid, $0.5 \mathrm{~g} / \mathrm{L} \mathrm{CoCl}{ }_{2}, 2 \mathrm{~mL} \mathrm{H} \mathrm{H}_{2} \mathrm{SO}_{4}$ ) and lasted for about $16 \mathrm{~h}$. Using $50 \%$ glycerol (w/v) containing $12 \mathrm{~mL} / \mathrm{L}$ of PTM1 as carbon sources, the fed-batch fermentation of glycerol was initiated at $16 \mathrm{~mL} / \mathrm{L} / \mathrm{h}$ for $3 \mathrm{~h}$. In the subsequent fermentation, the feeding rate 
was kept at $10 \mathrm{~mL} / \mathrm{L} / \mathrm{h}$ for $90 \mathrm{~h}$. The temperature and $\mathrm{pH}$ during fermentation were maintained at $30{ }^{\circ} \mathrm{C}$ and 5.0 , respectively. The dissolved oxygen was kept at around $20 \%$ and was automatically adjusted by cascading agitation speed $(600-1000 \mathrm{rpm})^{[42]}$. The cell cultures $(10 \mathrm{~mL})$ were collected at the same time intervals, and the supernatants were obtained by centrifugation at $6,000 \times \mathrm{g}$ and $4{ }^{\circ} \mathrm{C}$ for $20 \mathrm{~min}$ for the sodium dodecyl sulfate-polyacrylamide gel electrophoresis (SDS-PAGE) analysis ${ }^{[43]}$ and AGL activity determinations.

\subsection{Enzyme purification}

The culture supernatant was filtered with $0.45 \mu \mathrm{m}$ filters before being loaded on the column. Purification of the rAGL was performed with the AKTA Prime Plus (GEHealthcare Bio-science, Uppsala, Sweden) using a 5-mL high affinity Ni-Charged resin FF prepacked column (Genscript, Nanjing, China) ${ }^{[44]}$. After exchanging with sodium acetate buffer (100 mM, pH 4.0) and concentrated using an Amicon ${ }^{\circledR}$ Ultra-15 Centrifugal Filter Unit with an Ultracel-30 membrane (Merck Millipore Ltd., Ireland), the elute solution containing AGL was collected and stored at $4{ }^{\circ} \mathrm{C}$ for further experiments. The molecular weight of rAGL and protein purity were determined by $8 \%(\mathrm{w} / \mathrm{v})$ SDS-PAGE. The protein concentration was determined using the Bradford method [45].

\subsection{Enzyme assay}

AGL activity was measured by the release of glucose from maltose ${ }^{[46]}$. Each reaction mixture $(100 \mu \mathrm{L})$ containing $25 \mathrm{mM}$ maltose, $100 \mathrm{mM}$ sodium acetate buffer $(\mathrm{pH} 4.0$ ), and $10 \mu \mathrm{g}$ purified enzyme (or $20 \mu \mathrm{L}$ culture supernatant) was incubated for $10 \mathrm{~min}$ at $37{ }^{\circ} \mathrm{C}$. After heating at $100{ }^{\circ} \mathrm{C}$ for $7 \mathrm{~min}$, the glucose of 10 $\mu \mathrm{L}$ reaction mixture was assayed using the D-glucose GOD-POD colorimetric assay kit ${ }^{[47-48]}$. One activity unit was defined as the amount of enzyme that liberate $2 \mu \mathrm{mol}$ of glucose from maltose per minute under the above assay conditions.

The $\mathrm{pH}$ optimum of rAGL was measured in the range of $\mathrm{pH}$ 3.0-7.0 using $100 \mathrm{mM}$ sodium citrate buffer ( $\mathrm{pH} 3.0-3.5)$, sodium acetate buffer $(\mathrm{pH} 4.0-5.5)$ and sodium phosphate buffer ( $\mathrm{pH}$ 6.0-7.0), respectively. To determine the $\mathrm{pH}$ stability, rAGL $(2.12 \mathrm{mg} / \mathrm{mL})$ was preincubated in the various buffers described above at $4{ }^{\circ} \mathrm{C}$ for $24 \mathrm{~h}$ and $48 \mathrm{~h}$, and then the residual activity was assayed under the standard assay conditions ${ }^{[28]}$.

The optimal temperature of rAGL was measured at $\mathrm{pH} 4.0$ and temperatures range from $37{ }^{\circ} \mathrm{C}$ to 70 ${ }^{\circ} \mathrm{C}$, and maltose was used as substrate in $100 \mathrm{mM}$ acetate buffer. The thermal stability was determined by incubating rAGL $(2.12 \mathrm{mg} / \mathrm{mL}$ ) in $100 \mathrm{mM}$ acetate buffer $(\mathrm{pH} 4.0)$ at different temperatures (30-70 ${ }^{\circ} \mathrm{C}$ ). At each temperature, the buffer and rAGL were preincubated for $15 \mathrm{~min}, 30 \mathrm{~min}, 45 \mathrm{~min}$ and $1 \mathrm{~h}$, respectively. The reaction was initiated by adding maltose, and allowed to proceed for another $10 \mathrm{~min}$. At different time intervals, samples were collected and the residual activity was assayed under the standard assay conditions ${ }^{[28,37]}$.

To determine the influence of metal ions $\left(\mathrm{Cu}^{2+}, \mathrm{Ca}^{2+}, \mathrm{Mg}^{2+}, \mathrm{Mn}^{2+}, \mathrm{Zn}^{2+}, \mathrm{Fe}^{3+}, \mathrm{Fe}^{2+}\right)$ on enzyme activity, rAGL $(2.12 \mathrm{mg} / \mathrm{mL})$ was preincubated with each metal ion $(10 \mathrm{mM})$ in $100 \mathrm{mM}$ acetate buffer $(\mathrm{pH} 4.0)$ at $37^{\circ} \mathrm{C}$ for $1 \mathrm{~h}$. The residual enzyme activity was detected at $37^{\circ} \mathrm{C}$.

For determination of the Michaelis-Menten constants of rAGL, reactions were carried out under the standard assay conditions with different concentrations of maltose $(5-100 \mathrm{mM})$. After incubation for $10 \mathrm{~min}$, the reaction mixture was heated to $100 \mathrm{degC}$ for $7 \mathrm{~min}$ and analyzed by the GOD-POD method. On the basis of Michaelis-Menten kinetic model, the $K_{m}$ value of rAGL for maltose was determined by non-linear curve-fitting.

All reactions were conducted in triplicate. The relative activity (\%) was calculated in terms of that of the maximum activity (100\%).

\subsection{Transglycosylation catalyzed by rAGL}

The transglycosylation reaction was performed as previously described with modification ${ }^{[18]}$. Briefly, the reaction mixture $(0.3 \mathrm{~mL})$ consisted of $267 \mathrm{mM}$ maltose, $178 \mathrm{mM}$ ascorbic acid sodium salt $(\mathrm{AA} * \mathrm{Na}), 13 \mathrm{mM}$ thiourea, $1.12 \mathrm{U}$ of rAGL (in $150 \mu \mathrm{L}$ culture supernatant), and sodium acetate buffer (100 mM, pH 4.0), 
and was incubated in the dark at $37{ }^{\circ} \mathrm{C}$ for 1-6 h, unless otherwise specified. The samples taken every hour were mixed with $600 \mu \mathrm{L}$ of $1.06 \%$ (w/v) metaphosphoric acid to stop the reaction, and the solutions were centrifuged at $12000 \times g$ for $10 \mathrm{~min}$. The supernatant was collected and stored at $-20{ }^{\circ} \mathrm{C}$ waiting for high performance liquid chromatography (HPLC) analysis. On the basis of the initial reaction condition, that is, the reaction last for $6 \mathrm{~h}$ at $37^{\circ} \mathrm{C}, \mathrm{pH} 4.0$, with the molar ratio of maltose to AA.Na set to $3: 2$, the influence of reaction temperature $(30,37,40,45$, and $50 \mathrm{degC}), \mathrm{pH}(100 \mathrm{mM}$ sodium citrate buffer at $\mathrm{pH} 3.0-3.5$ and $100 \mathrm{mM}$ sodium acetate buffer at $\mathrm{pH} 4.0-5.5)$, and maltose/AA*Na molar ratio (1:1, 3:1 and 3:2) on the synthesis of AA-2G catalyzed by rAGL was investigated. Besides, the influence of enzyme concentrations on AA-2G synthesis was also investigated. The reaction mixture was scaled up to $10 \mathrm{~mL}$, containing 267 $\mathrm{mM}$ maltose, $267 \mathrm{mM} \mathrm{AA}{ }^{*} \mathrm{Na}, 13 \mathrm{mM}$ thiourea, various concentrations of rAGL $(1,2,3$ and $4 \mathrm{U} / \mathrm{mL})$, and sodium acetate buffer (100 mM, pH 4.0), and was incubated in the dark with shaking at $37 \mathrm{deg}$ for 1-8 h. All samples $(200 \mu \mathrm{L})$ collected each hour were mixed with $600 \mu \mathrm{L}$ of $1.06 \%(\mathrm{w} / \mathrm{v})$ metaphosphoric acid to stop the reaction. Other treatments to the samples were the same as the above.

\subsection{HPLC analysis}

The above-mentioned supernatants were thawed at room temperature. After proper dilution, the filtered samples were analyzed on an Agilent 1260 HPLC system (Agilent Technologies, The Netherlands), using an Agilent TC-C18 column (150 mm x $4.6 \mathrm{~mm}$; Agilent Technologies), maintaining at $25{ }^{\circ} \mathrm{C}$ with UV detection at $238 \mathrm{~nm}$. The flow rate was $0.8 \mathrm{~mL} / \mathrm{min}$ using $1 \%$ HPLC grade methanol (pH adjusted to 2 with phosphoric acid) as the mobile phase. The injection volume was $10 \mu \mathrm{L}$. The AA-2G concentration was calculated on the basis of peak area of the standard samples.

\section{Results}

\subsection{Cloning and expression of rAGL in P. pastoris}

The coding region derived from $O$. sativa AGL excluding the fragment of its original signal peptide but with an $N$-terminal 6-histidine tag, was synthesized and cloned into the plasmid pGAP9K, which was fused with $\alpha$-Factor signal sequence of the plasmid for secretion in Pichia under the control of $\mathrm{P}_{\mathrm{GAP}}$. Subsequently, the genomic integration was carried out by transformation of the linearized plasmid DNA that was digested using Psh AI, intoP. pastoris GS115. The transformed cells were spread on MD agar plates. Positive transformants containing high copy number of AGL gene were obtained through screening on YPD plates with different concentrations of geneticin. As a result, 12 clones were selected from the plates containing $4 \mathrm{mg} / \mathrm{mL}$ geneticin, among which four clones were confirmed by colony PCR with four sets of primers (Supplementary Figure 1) and selected for the subsequent expression experiments.

Expression levels of four selected clones were tested in the shake flask culture. Samples were collected every $12 \mathrm{~h}$, and protein concentration and enzyme activity in the culture supernatant were detected. The growth profiles of cell mass $\left(\mathrm{OD}_{600}\right)$ for the four recombinant clones were similar and could reach the highest value of $58.4 \pm 3.7$ at $72 \mathrm{~h}$, when the one having the maximum protein concentration $(0.114 \mathrm{mg} / \mathrm{mL})$ and enzyme activity $(1.48 \mathrm{U} / \mathrm{mL})$ was used for scale-up fermentation and rAGL production.

\subsection{High-density fermentation in a 5-L fermenter}

A scale-up fermentation was carried out in a 5-L fermenter, and samples were collected every $6 \mathrm{~h}$ to analyze $\mathrm{OD}_{600}$, total protein concentration, and enzyme activity. The whole process of high-density fermentation lasted for $108 \mathrm{~h}$. As is showed in Fig. 2, in the fed-batch with glycerol as carbon source, $\mathrm{OD}_{600}$ increased continuously, reaching the highest value of $716 \pm 15$ at $102 \mathrm{~h}$, and then decreased, which may be due to the fact that the dissolved oxygen can not maintain the growth of such high density cells under the experimental conditions. In the 102-h sample, the total protein concentration and AGL activity in the culture supernatant were as high as $0.732 \mathrm{mg} / \mathrm{mL}$ and $9.11 \mathrm{U} / \mathrm{mL}$, respectively, which exhibited the same growth trend as cell mass.

Figure 2 


\subsection{Purification of rAGL and kinetic analysis}

$N$-terminal his-tagged rAGL in culture supernatant was purified by Ni-NTA affinity chromatography. The details of purification are shown in Table 1 . At $37^{\circ} \mathrm{C}$ and $\mathrm{pH} 4.0$, the specific activity of rAGL is $49.83 \mathrm{U} /$ mg. In SDS-PAGE, rAGL with an $N$-terminal 6-histidine showed a band of roughly $100 \mathrm{kDa}$ (Fig. 3).

The kinetic parameters of rAGL were analyzed using maltose as the substrate at $37^{\circ} \mathrm{C}$ and $\mathrm{pH} 4.0$ (Supplementary Figure 2). As a result, the kinetic constants $K_{m}, V_{\max }$ and $K_{\text {cat }}$ of the rAGL were found to be 61 $\mathrm{mM}, 184.64 \mathrm{U} / \mathrm{mg}$, and $146.70 \mathrm{1} / \mathrm{s}$, respectively.

Table 1

Figure 3

\subsection{Characterisation of biochemical properties}

The $\mathrm{pH}$ effect on rAGL activity was shown in Fig. 4a. rAGL activity reached its maximum at $\mathrm{pH}$ 4.0. Under the standard condition, it showed high enzymatic activity ( $>90 \%$ of maximum value) between $\mathrm{pH} 3.0$ and $\mathrm{pH}$ 5.0. Furthermore. rAGL was stable at $\mathrm{pH} 3.0-4.5$, and retained $99 \%$ and $97 \%$ activity after incubation at $\mathrm{pH} 4.0$ for $48 \mathrm{~h}$ and $72 \mathrm{~h}$, respectively (Fig. $4 \mathrm{~b}$ ).

The optimum temperature for rAGL was $65{ }^{\circ} \mathrm{C}$, and it has high activity between $60{ }^{\circ} \mathrm{C}$ and $65{ }^{\circ} \mathrm{C}$ (Fig.4c). rAGL was stable between $37{ }^{\circ} \mathrm{C}$ and $55^{\circ} \mathrm{C}$, and remained more than $80 \%$ activity after 60 min of incubation (Fig.4d). However, when the temperature was kept at $65{ }^{\circ} \mathrm{C}$ for $15 \mathrm{~min}$, rAGL lost $50 \%$ of its activity.

In this study, the metal requirement of rAGL was investigated using $10 \mathrm{mM}$ metal ions $\left(\mathrm{Cu}^{2+}, \mathrm{Ca}^{2+}, \mathrm{Mg}^{2+}\right.$, $\mathrm{Mn}^{2+}, \mathrm{Zn}^{2+}, \mathrm{Fe}^{3+}$ and $\mathrm{Fe}^{2+}$ ). rAGL was pre-incubated with each metal ion, and its activity was gauged. As is displayed in Fig.5, none of these metals significantly affected rAGL activity, which suggested that this enzyme is insensitive to the metal ions under the experimental conditions.

Figure 4

Figure 5

\subsection{Formation of AA-2G catalyzed by rAGL}

In the present, rAGL from $O$. sativa catalyzed the glycosylation of AA-Na to produce AA-2G, a stable L-ascorbic acid derivative. The proceeding of AA-2G synthesis was monitored by HPLC. As is shown in Fig. 6, using maltose as the glycosyl donor, the influences of $\mathrm{pH}$, temperature, substrate ratio and enzyme concentration on AA-2G production catalyzed by rAGL were studied.

Among the $\mathrm{pH}$ range of 3.0 to 5.5 (Figure $6 \mathrm{a}$ ), the product concentration in the reaction mixture increased obviously in the first $3 \mathrm{~h}$, and then declined possibly because of the hydrolytic activity of rAGL. At pH 4.0, the highest yield of AA-2G $(6.73 \pm 0.02 \mathrm{~g} / \mathrm{L})$ was obtained within $3 \mathrm{~h}$, and after $3 \mathrm{~h}$, the concentration of AA-2G decreased faster at $\mathrm{pH} 3.0$ than at other $\mathrm{pH}$ values.

As is indicated in Fig. 6b, the optimum temperature of glycosylation reaction appears to be $37^{\circ} \mathrm{C}$, because the concentration of AA-2G remains higher than other conditions within $6 \mathrm{~h}$. Among the different reaction temperatures, decrease of the AA-2G concentration was observed from the beginning (reaction of $1 \mathrm{~h}$ ) at 50 ${ }^{\circ} \mathrm{C}$, probably degradation of the substate AA $\mathrm{Na}$ at high temperature is a factor that can not be ignored. At $30{ }^{\circ} \mathrm{C}$, AA-2G increased in $2 \mathrm{~h}$, and then remained basically unchanged within the next $4 \mathrm{~h}$.

As for the influence of the molar ratio of maltose/AA-Na on the synthesis of AA-2G (Fig. 6c), when maltose is kept at $267 \mathrm{mM}$ in the initial reaction system, the highest product concentration can increase with the rise of AA·Na concentration (from $89 \mathrm{mM}$ to $267 \mathrm{mM}$ ). Excessive maltose increased the reaction rate and affected the yield from AA·Na. In the case that the maltose/AA·Na molar ratio was 1:1, the AA-2G concentration in the reaction mixture topped $8.7 \pm 0.4 \mathrm{~g} / \mathrm{L}$ after reaction for $3 \mathrm{~h}$, and the yield from AA.Na was $9.7 \%$. The higher yield $(10.6 \%)$ was achieved in $2 \mathrm{~h}$ at the maltose/AA-Na ratio of $3: 2$, although the AA-2G concentration was only $6.4 \pm 0.1 \mathrm{~g} / \mathrm{L}$. 
The enzyme concentration has an effect on the reaction rate as well, as was presented in Fig. 6d. The formation patterns of AA-2G are similar that the product increased firstly until it approaches the high summit, and then the reaction decreased, but with the increase of enzyme amount, the time to reach the highest concentration was shortened. Under the condition of $4 \mathrm{U} / \mathrm{mL}$ rAGL, $7.5 \pm 0.3 \mathrm{~g} / \mathrm{L}$ of AA-2G can be produced within $2 \mathrm{~h}$, but its hydrolysis rate was also higher than other reactions with lower enzyme concentration. The highest yield of AA-2G $(8.3 \pm 0.7 \mathrm{~g} / \mathrm{L})$ was reached in $5 \mathrm{~h}$ of the reaction with $2 \mathrm{U} / \mathrm{mL}$ of rAGL.

Figure 6

\section{Discussion}

A large number of AGLs were found in mammals, plants, and microorganisms. Regarding the production of rAGL, up to now, most bacterial enzymes from Sulfolobus tokodaii ${ }^{[49]}$, Thermoplasma acidophilum ${ }^{[50]}$, Pyrobaculum aerophilum ${ }^{[51]}$, and Bifidobacterium longum ${ }^{[52]}$, were overexpressed in E. coli , and several AGLs from plants and fungi like barley ${ }^{[48]}$, Rice ${ }^{[53]}$, Aspergillus niger ${ }^{[54]}$, were successfully produced in $P$. pastoris. In the previous work, efforts have been made to produce the rAGL of glycoside hydrolase family GH31 from higher plants in $E$. coli, but resulted in no or rather low enzyme activity ${ }^{[55-56]}$. It was not until 2006 that the AGL from barley (Hordeum vulgare) with fully activity was produced in P. pastoris for the first time ${ }^{[47-48]}$. Since then, P. pastoris system that is widely used to produce heterologous proteins from various organisms involving viruses, bacteria, fungi, plants, animals and humans ${ }^{[57]}$, also greatly promotes the heterologous production of AGL (Table 2).

Table 2

Previously, when two isoforms of ONG2 were purified from dry rice seeds, native AGL from O. sativa has been characterized ${ }^{[53,58]}$. In this study, rAGL corresponding to the ONG2 was found only one bandlarger than 97.2 KDa (Fig. 3), probably due to the lack of post-translational proteolysis occurring inPichia. The $K_{m}$ value of rAGL for maltose was $61 \mathrm{mM}$, which indicates that the affinity to maltose is lower than that of native ONG2-I and ONG2-II, which are $2.1 \mathrm{mM}$ and $2.3 \mathrm{mM}$ respectively. As well, rAGL appeared to possess lower specific activity $(49.83 \mathrm{U} / \mathrm{mg})$ than that of the ONG2-I $(122 \mathrm{U} / \mathrm{mg})$ and ONG2-II $(124 \mathrm{U} / \mathrm{mg})$, although the assay conditions were not completely the same. Comparison of biochemical characteristics of native AGLs from $O$. sativa and recombinant enzyme from $P$. pastoris indicated that they had similar optimal $\mathrm{pH}$ and remained active in a wide $\mathrm{pH}$ range. Native AGLs in plants prefer to be close to the temperature of the growing environment. However, rAGL was stable at up to $55{ }^{\circ} \mathrm{C}$ and the highest optimal temperature $(65$ ${ }^{\circ} \mathrm{C}$ ) of enzyme activity, which demonstrates better thermal stability than native informs, which was stable as high as $40{ }^{\circ} \mathrm{C}$, and completely lost its activity after incubation at $60{ }^{\circ} \mathrm{C}$ for $10 \mathrm{~min}$. It should be noted that thermal stability of rAGL is an important factor related to its potential applications in biotechnology.

Thanks to the transglycosylation activity, AGLs are potentially to be effectively useful in the preparation of AA-2G (Fig. 7). The production of AA-2G was facilitated under optimized conditions $\left(40^{\circ} \mathrm{C}\right.$ and $\left.\mathrm{pH} 6.0\right)$ by a truncated AGL from $A$. niger and the highest yield of AA-2G reached $0.528 \pm 0.04 \mathrm{~g} / \mathrm{L}{ }^{[19]}$. As far as we know, the yield of AA-2G in the present study represents the highest by AGLs reported so far, reaching $8.7 \pm 0.4 \mathrm{~g} / \mathrm{L}$ at $37^{\circ} \mathrm{C}$ and $\mathrm{pH}$ 4.0. Among the results of reactions, a typical ' $\mathrm{n}$ '-shaped kinetic profile of the AA-2G formation was observed. By understanding the glucosidase-catalyzed glycosylation process in waterrich environment ${ }^{[59]}$, it can be concluded that glycosylation is dominant at the beginning of reaction, which leads to rapid synthesis of AA-2G. At the same time, the synthesized AA-2G started to degrade with time. In the batch system, the AA conversion is thermodynamically restricted, and the catalytic efficiency is mainly impacted by the selectivity of AGL's glycosylation/hydrolysis. In the case of the different maltose/AA.Na ratios (Fig. 6c), it can be concluded that high glycosyl donor (maltose) content helped to slow down the rate of hydrolysis and therefore have an influence on the catalytic efficiency. However, the amount of rAGL only has the effect on the reaction rate but does not affect the equilibrium of glycosylation and hydrolysis (Fig. 6d). In order to maximize the product accumulation, the decomposition of AA at inappropriate $\mathrm{pH}$ and temperatures should never be neglected (Fig. 6a and 6b). 
Figure 7

In summary, AGL from O. sativa was expressed in P. pastoris, which proved to be beneficial in fermentation process, allowing the production of enough enzyme and promoting enzymatic synthesis of AA-2G by AGLs. To date, the full potential of rAGL has not been fully realized in this study and further work is needed to improve enzyme activity for transglycosylation, such as controlling the conditions of glycosylation reactions ${ }^{[60]}$ and enzyme technology to create a glycosynthase ${ }^{[61]}$. These studies will provide the basis for the application of rAGL in AA-2G industrial production.

\section{Acknowledgments}

This study was funded by the NSFC (21878155), Qing Lan Project of Jiangsu Universities, and Six Talent Peaks Project in Jiangsu Province, the Jiangsu Synergetic Innovation Center for Advanced Bio-manufacture, and PAPD.

\section{Author statement}

Yan Li: Conceptualization, Methodology, Supervision, Funding acquisition

Xuelian Qi: Investigation, Writing - Original Draft, Writing-review and editing

Honghua Jia: Resources, Project administration, Writing - Review \& Editing Preparation

Junlan Shao : Investigation, Data curation

Yinchu Chen: Investigation, Visualization

Xiaoying He: Investigation,Writing - Review

Ming Yan: Supervision, Resources

Declaration of competing interest

None

\section{References}

[1] S. Chambial, S. Dwivedi, K.K. Shukla, P.J. John, P. Sharma, Indian J Clin Biochem 2013, 28, 314.

[2] S. Mousavi, S. Bereswill, M.M. Heimesaat, Eur J Microbiol Immunol (Bp) 2019, 9, 73.

[3] J. Teng, A. Pourmand, M.M. Amirshahi, J Crit Care 2018, 43, 230.

[4] S.C. Rumsey, M. Levine, J Nutr Biochem 1998, 9, 116.

[5] M.C.D. Tullio, Nature Education 2010, 3, 48.

[6] S.H. LEE,T.P. LABUZA, J Food Sci 1975, 40, 370.

[7] M.H.Eison-Perchonok., T.W.Downes, J Food Sci 1982, 47, 765.

[8] A.M Rojas, L.N Gerschenson, J Sci Food Agr 1997, 74, 369.

[9] A.L. Herbig, C.M.G.C, Renard, Food Chem 2017, 220, 444.

[10] C.G.Mead, F.J. Finamore, Biochemistry 1969, 8, 2652.

[11] Ascorbic acid sulfate (AAS): A metabolite of ascorbic acid with antiscorbutic activity. Nutrition Reviews 1973, 31, 251.

[12] H.J. Hsieh, G.R. Nair, W.T. WU, J Agric Food Chem 2006, 54, 5777.

[13] M.G. Yadav, M.R. Kavadia, R.N. Vadgama, A.A. Odaneth, A.M. Lali, Appl Biochem Biotechnol 2018, $184,1168$. 
[14] N. Muto, T.Nakamura, I. Yamamoto, J Biochem 1990, 107, 222.

[15] H.K. Jun, K.M. Bae, S.K. Kim, Biotechnol Lett 2001, 23, 1793.

[16] R. Han, L. Liu, J. Li, G. Du, J. Chen, Appl Microbiol Biotechnol 2012, 95, 313.

[17] Y. Hanada, A. Iomori, R. Ishii, E. Gohda, A. Tai, Biosci Biotechnol Biochem 2014, 78, 301.

[18] N. Muto, S. Suga, K. Fujii, K. Goto, I. Yamamoto, Agricultural and Biological Chemistry 1990, 54, 1697.

[19] Z. Li, H. Han, B. Wang, J. Gao, B. Zhu, R. Peng, Q. Yao, J Food Biochem 2017, 41.

[20] Y. Jiang, J. Zhou, R. Wu, F. Xin, W. Zhang, Y. Fang, J. Ma, W. Dong, M. Jiang, BMC Biotechnol $2018,18,53$.

[21] X. Tao, T. Wang, L. Su, J. Wu, J Agric Food Chem 2018, 66, 9052.

[22] S.B. Lee, K.C. Nam, S.J. Lee, J.H. Lee, K. Inouye, K.H. Park, Biosci Biotechnol Biochem 2004, 68, 36.

[23] T. Kwon, C.T. Kim, J.H. Lee, Biotechnol Lett 2007, 29, 611.

[24] Y. Li, Z. Li, X. He, L. Chen, Y. Cheng, H. Jia, M. Yan, K. Chen, J Biotechnol 2019, 305, 27.

[25] M. Kubota, K. Tsusaki, T. Higashiyama, S. Fukuda, T. Miyake, Patent application, 2007.

[26] I. Yamamoto, N. Muto, K. Murakami, S. Suga, H. Yamaguchi, Chem Pharm Bull (Tokyo) 1990, 38, 3020 .

[27] I. Yamamoto, N. Muto, E. Nagata, T. Nakamura, Y. Suzuki, Biochim Biophys Acta 1990, 1035, 44.

[28] D.L. Chen, X. Tong, S.W. Chen, S. Chen, D. Wu, S.G. Fang, J. Wu, J. Chen, J Agric Food Chem 2010, $58,4819$.

[29] M. Okuyama, W. Saburi, H. Mori, A. Kimura, Cell Mol Life Sci 2016, 73, 2727.

[30] M. Okuyama, Biosci Biotechnol Biochem 2011, 75, 2269.

[31] M. Sugimoto, S. Furui, K. Sasaki, Y. Suzuki, Biosci Biotechnol Biochem 2003, 67, 1160.

[32] S. Mala, H. Dvorakova, R. Hrabal, B. Kralova, Carbohyd Res 1999, 322, 209.

[33] K.M. Song, M. Okuyama, K. Kobayashi, H. Mori, A. Kimura, Biosci Biotechnol Biochem 2013, 77, 2117.

[34] M. Casa-Villegas, J. Marin-Navarro, J. Polaina, ACS Omega 2017, 2, 8062.

[35] V. Looser, B. Bruhlmann, F. Bumbak, C. Stenger, M. Costa, A. Camattari, D. Fotiadis, K. Kovar, Biotechnol Adv 2015, 33, 1177.

[36] S. Kumar, S. Mutturi, Enzyme Microb Technol 2020, 141, 109653.

[37] M. Ma, M. Okuyama, T. Tagami, A. Kikuchi, P. Klahan, A. Kimura, J Agric Food Chem 2019, 67, 3380 .

[38] J. Kaewmuangmoon, M. Kilaso, U. Leartsakulpanich, K. Kimura, A. Kimura, C. Chanchao, BMC Biotechnol 2013, 13, 16.

[39] A. Zhang, J. Luo, T. Zhang,Y. Pan, Y. Tan, C. Fu, F. Tu, Mol Biol Rep 2009, 36, 1611.

[40] J. Lin-Cereghino, W.W. Wong, S. Xiong, W. Giang, L.T. Luong, J. Vu, S.D. Johnson, G.P. LinCereghino, Biotechniques 2005, 38, 44.

[41] C.A. Scorer, J.J. Clare, W.R. McCombie, M.A. Romanos, K. Sreekrishna, Biotechnology (N Y) 1994, $12,181$. 
[42] M. Karaoglan, F.E. Karaoglan, M. Inan, Protein Expr Purif 2016, 121, 112.

[43] H.Schagger, G. von Jagow, Anal Biochem 1987, 166, 368.

[44] L. Chen, R. Cai, J. Weng, Y. Li, H. Jia, K. Chen, M. Yan, P. Ouyang, Microb Biotechnol 2020, 13, 974.

[45] M.M. Bradford, Anal Biochem 1976, 72, 248.

[46] E.H. Muslin, A.M. Kanikula, S.E. Clark, C.A. Henson, Protein Expr Purif 2000, 18, 20.

[47] T.P. Frandsen, F. Lok, E. Mirgorodskaya, P. Roepstorff, B. Svensson, Plant Physiol 2000, 123, 275.

[48] H. Naested, B. Kramhoft, F. Lok, K. Bojsen, S. Yu, B. Svensson, Protein Expr Purif 2006, 46, 56.

[49] J.E. Park, S.H. Park, J.Y. Woo, H.S. Hwang, J. Cha, H. Lee, J Microbiol Biotechnol 2013, 23, 56.

[50] I. Park, H. Lee, J. Cha, Biotechnol Lett 2014, 36, 789.

[51] H. Jeon, H. Lee, D. Byun, H. Choi, J.-H. Shim, Food Sci Biotechnol 2015, 24, 175.

[52] N.R. Kim, D.W. Jeong, D.S. Ko, J.H. Shim, Int J Biol Macromol 2017, 99, 594.

[53] H. Nakai, T. Ito, M. Hayashi, K. Kamiya, T. Yamamoto, K. Matsubara, Y.M. Kim, W. Jintanart, M. Okuyama, H. Mori, S. Chiba, Y. Sano, A. Kimura, Biochimie 2007, 89, 49.

[54] X. Liu, D. Wu, J. Wu, J. Chen, World J Microbiol Biotechnol 2013, 29, 533.

[55] B.K. Tibbot, C.A. Henson, R.W. Skadsen, Plant Mol Biol 1998, 38, 379.

[56] M.A. Taylor, H.A. Ross, D. McRae, F. Wright, R. Viola, H.V. Davies, Planta 2001, 213, 258.

[57] J.L. Cereghino, J.M. Cregg, FEMS Microbiol Rev 2000, 24, 45.

[58] H. Nakai, S. Tanizawa, T. Ito, K. Kamiya, Y.M. Kim, T. Yamamoto, K. Matsubara, M. Sakai, H. Sato, T. Imbe, M. Okuyama, H. Mori, Y. Sano, S. Chiba, A. Kimura, J Biochem 2007, 142, 491.

[59] H. Chen, S. Yang, A. Xu, R. Jiang, Z. Tang, J. Wu, L. Zhu, S. Liu, X. Chen, Y. Lu, Appl Microbiol Biotechnol 2019, 103, 9423.

[60] H. Chen, X. Jin, L. Zhu, Y. Lu, Z. Ma, S. Liu, X. Chen, Appl Microbiol Biotechnol 2020, 104, 9523.

[61] M. Yang, G.J. Davies, B.G. Davis, Angew Chem Int Ed Engl 2007, 46, 3885.

\section{Tables}

Table 1 Summary of purification of rAGL from the recombinant $P$. pastoris .

\begin{tabular}{|c|c|c|c|c|}
\hline Step & Total protein $(\mathrm{mg})$ & Total activity (U) & $\begin{array}{l}\text { Specific activity } \\
(\mathrm{U} / \mathrm{mg})\end{array}$ & Yield (\%) \\
\hline $\begin{array}{l}\text { Culture } \\
\text { supernatant }\end{array}$ & 208.8 & 2653.85 & 12.71 & 100 \\
\hline $\begin{array}{l}\text { Ni-NTA column } \\
\text { purification }\end{array}$ & 12.69 & 632.34 & 49.83 & 23.8 \\
\hline
\end{tabular}

Table 2 rAGLs of glycoside hydrolase family GH31 produced in P. pastoris .

\begin{tabular}{lllll}
\hline Origin & Promoter & Enzyme activity $^{\mathrm{a}}$ & Enzyme activity $^{\mathrm{a}}$ & References \\
\hline & & Culture supernatant & Purified rAGL & \\
A. niger & $\mathrm{P}_{\text {AOX1 }}$ & $2.07 \mathrm{U} / \mathrm{mL} ; 2.21 \mathrm{U} / \mathrm{mg}$ & $2.52 \mathrm{U} / \mathrm{mg}$ & {$[28]$} \\
H. vulgare & $\mathrm{P}_{\text {AOX1 }}$ & $1 \mathrm{U} / \mathrm{mg}$ & $25.6 \mathrm{U} / \mathrm{mg}$ & {$[48]$}
\end{tabular}




\begin{tabular}{lllll}
\hline Origin & Promoter & Enzyme activity ${ }^{a}$ & Enzyme activity $^{a}$ & References \\
\hline Podospora anserina & $\mathrm{P}_{\mathrm{GAP}}$ & $1.03 \mathrm{U} / \mathrm{mL}$ & $41.1 \mathrm{U} / \mathrm{mg}$ & {$[33]$} \\
A. niger & $\mathrm{P}_{\mathrm{GAP}}$ & n.a. & $33.1 \mathrm{U} / \mathrm{mg}$ & {$[37]$} \\
O. sativa & $\mathrm{P}_{\mathrm{GAP}}$ & $9.11 \mathrm{U} / \mathrm{mL} ; 12.71 \mathrm{U} / \mathrm{mg}$ & $49.83 \mathrm{U} / \mathrm{mg}$ & This study \\
\hline
\end{tabular}

Note: a) ${ }^{a}$ Maltose is used as the substrate for activity assay; b) M.W., molecular weight; c) n.a., not available.

Figure legends

Figure 1 The plasmid construct used for extracellular expression of rAGL.

Figure 2 Fermentation curves of the recombinant $P$. pastoris in a 5-L fermenter, including optical density $\left({ }^{\prime}\right.$, protein concentration () , and enzyme activity $(*)$.

Figure 3 SDS-PAGE analysis of the extracellular rAGL expressed in the engineered $P$. pastoris. Lane M, molecular weight markers; Lane 1, culture supernatant; Lane 2, purified rAGL. The band corresponding to rAGL is indicated with an arrow.

Figure 4 Effects of $\mathrm{pH}$ and temperature on the activity and stability of rAGL .

Figure 5 Effect of metal ions on the activity of rAGL.

Figure 6 Influence of the factors including the reaction $\mathrm{pH}(\mathrm{A})$, temperature $(\mathrm{B})$, maltose/AA.Na molar ratio (C) and enzyme concentration (D) on AA-2G production.

Figure 7 Synthesis of AA-2G by rAGL with maltose and AA as the substrates.

Figures

Figure 1 


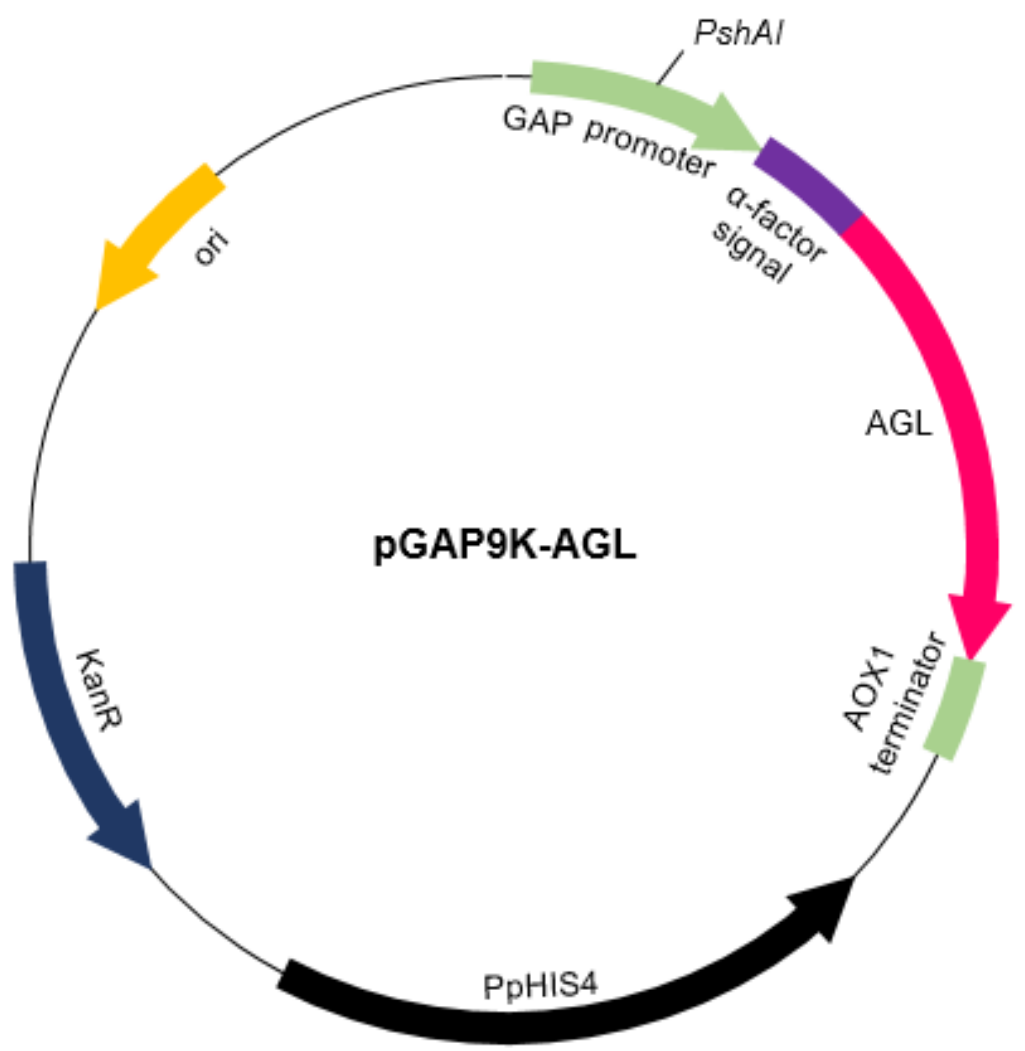

Figure 2

Hosted file

image2.emf available at https://authorea.com/users/413834/articles/522021-extracellularexpression-and-characterization-of-an-\%CE\%B1-glucosidase-from-oryza-sativa-and-itstransglycosylation-for-synthesis-of-2-o-\%CE\%B1-d-glucopyranosyl-l-ascorbic-acid

Figure 3 


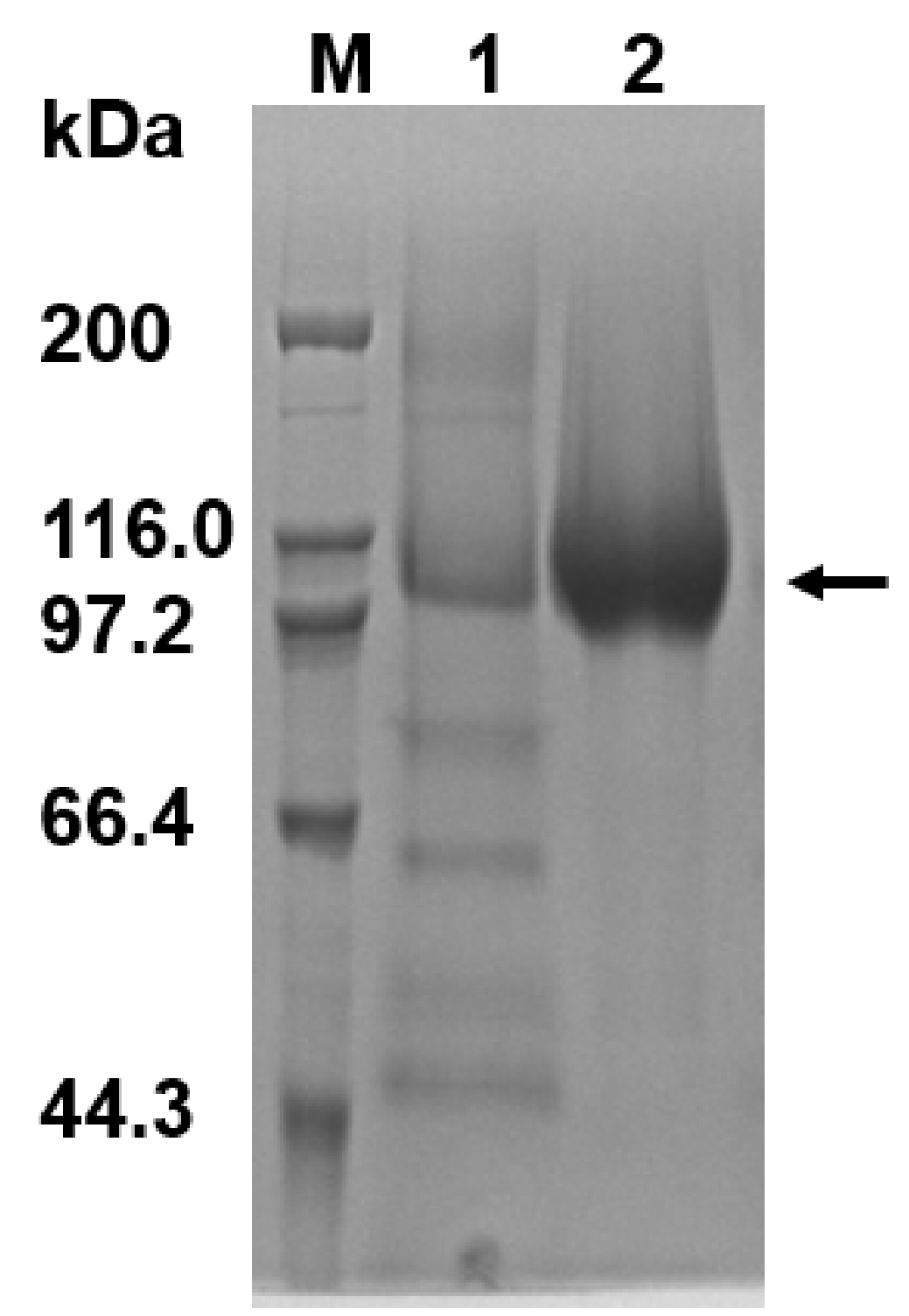

Figure 4

A

Hosted file

image4.emf available at https://authorea.com/users/413834/articles/522021-extracellularexpression-and-characterization-of-an-\%CE\%B1-glucosidase-from-oryza-sativa-and-itstransglycosylation-for-synthesis-of-2-o-\%CE\%B1-d-glucopyranosyl-l-ascorbic-acid

B

Hosted file 
image5.emf available at https://authorea.com/users/413834/articles/522021-extracellularexpression-and-characterization-of-an-\%CE\%B1-glucosidase-from-oryza-sativa-and-itstransglycosylation-for-synthesis-of-2-o-\%CE\%B1-d-glucopyranosyl-l-ascorbic-acid

\section{C}

\section{Hosted file}

image6.emf available at https://authorea.com/users/413834/articles/522021-extracellularexpression-and-characterization-of-an-\%CE\%B1-glucosidase-from-oryza-sativa-and-itstransglycosylation-for-synthesis-of-2-o-\%CE\%B1-d-glucopyranosyl-1-ascorbic-acid

\section{D}

\section{Hosted file}

image7.emf available at https://authorea.com/users/413834/articles/522021-extracellularexpression-and-characterization-of-an-\%CE\%B1-glucosidase-from-oryza-sativa-and-itstransglycosylation-for-synthesis-of-2-o-\%CE\%B1-d-glucopyranosyl-l-ascorbic-acid

Figure 5

\section{Hosted file}

image8.emf available at https://authorea.com/users/413834/articles/522021-extracellularexpression-and-characterization-of-an-\%CE\%B1-glucosidase-from-oryza-sativa-and-itstransglycosylation-for-synthesis-of-2-o-\%CE\%B1-d-glucopyranosyl-l-ascorbic-acid

\section{Figure 6}

\section{A}

\section{Hosted file}

image9.emf available at https://authorea.com/users/413834/articles/522021-extracellularexpression-and-characterization-of-an-\%CE\%B1-glucosidase-from-oryza-sativa-and-itstransglycosylation-for-synthesis-of-2-o-\%CE\%B1-d-glucopyranosyl-l-ascorbic-acid

\section{B}

\section{Hosted file}

image10.emf available at https://authorea.com/users/413834/articles/522021-extracellularexpression-and-characterization-of-an-\%CE\%B1-glucosidase-from-oryza-sativa-and-itstransglycosylation-for-synthesis-of-2-o-\%CE\%B1-d-glucopyranosyl-l-ascorbic-acid

\section{C}

\section{Hosted file}

image11.emf available at https://authorea.com/users/413834/articles/522021-extracellularexpression-and-characterization-of-an-\%CE\%B1-glucosidase-from-oryza-sativa-and-itstransglycosylation-for-synthesis-of-2-o-\%CE\%B1-d-glucopyranosyl-l-ascorbic-acid

\section{D}

\section{Hosted file}

image12.emf available at https://authorea.com/users/413834/articles/522021-extracellularexpression-and-characterization-of-an-\%CE\%B1-glucosidase-from-oryza-sativa-and-itstransglycosylation-for-synthesis-of-2-o-\%CE\%B1-d-glucopyranosyl-l-ascorbic-acid

\section{Figure 7}




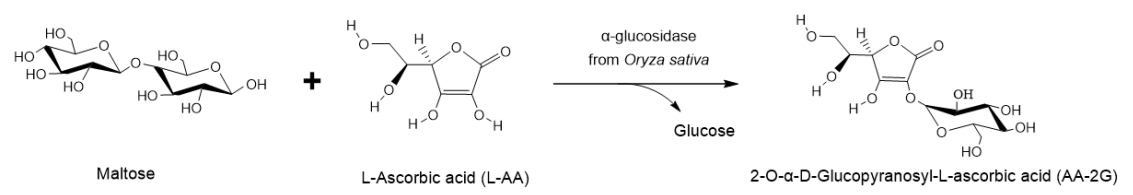

